\title{
PERAN ORANG TUA DALAM MENDUKUNG KEGIATAN PEMBELAJARAN ANAK SMP DI RUMAH PADA MASA PANDEMI COVID-19 DI DESA KUMPULREJO KECAMATAN PARENGAN KABUPATEN TUBAN TAHUN PELAJARAN 2020/2021
}

${ }^{1)}$ Ninik Hidayati, IAINU Tuban, email: ninikhidayati@stitmatuban.ac.id
${ }^{2)}$ Ika Wulandari, IAINU Tuban, email: ikawulandari249@gmail.com

\section{ABSTRACT}

Education outside the family, does not mean relinquishing the responsibility of parents in the world of education, this is done by parents due to the limited knowledge possessed by parents. But there are things that become cloudy in the process of children's learning activities carried out online. Based on the background of the problem, this researcher is expected to provide answers to the formulation of the problem described: 1) What is the role of parents in supporting the learning activities of junior high school children at home during the covid-19 pandemic in Kumpulrejo Village, Parengan District, Tuban Regency. 2) What are the inhibiting and supporting factors for junior high school children's learning activities at home during the COVID-19 pandemic in Kumpulrejo Village, Parengan District, Tuban Regency. The purpose of this study was 1) To determine the role of parents in supporting learning activities for junior high school children at home during the COVID-19 pandemic in Kumpulrejo Village, Parengan District, Tuban Regency. 2) to find out the inhibiting and supporting factors for junior high school children's learning activities at home during the covid-19 pandemic in Kumpulrejo Village, Parengan District, Tuban Regency

This study used a qualitative descriptive research method which took place in the village of Kumpulrejo. The process of collecting research data using the methods of observation, interviews and documentation. The data analysis technique used is data reduction, data display, conclusion drawing or data verification (conclusion drawing/verification).

The results of this study can be concluded that the role of parents in supporting the learning activities of junior high school children at home during the COVID-19 pandemic in Kumpulrejo Village, Parengan District, Tuban Regency is very important for their children. Children will be more enthusiastic about online learning which is done at home with the role of parents providing motivation and enthusiasm for children, parents as facilitators, parents supervising children in learning. The role of parents in the learning process at home has been carried out well. Although there were obstacles with the existence of civid-19 this research also went smoothly.

Keywords : The Role of Parents, Learning Activities, The Covid-19 Pandemic Period

\section{Pendahuluan}

Pendidikan merupakan upaya untuk meningkatkan kualitas siswa setelah melalui usahausaha belajar untuk mencapai tujuan tertentu dan yang diinginkan. Tujuan yang diinginkan yaitu sisiwa mampu mengembangkan potensi yang ada pada dirinya sehingga dapat berguna bagi diri sendiri dan orang lain. 
Sehubungan dengan hal tersebut dalam Undang-Undang No. 20 Tahun 2003 tentang sisitem Pendidikan Nasional menyatakan bahwa pendiddikan adalah usaha sadar terencana untuk mewujudkan suasana belajar dan proses pembelajaran agar peserta didik secara aktif mengembangkan potensi dirinya untuk memiliki kekuatan spiritual keagamaan, pengendalian diri, kepribadian, kecerdasan, akhlak mulia, serta keterampilan yang diperlukan dirinya, masyarakat, bangsa, dan negara. ${ }^{1}$

Pembelajaran dapat menjadi sarana untuk menggembangkan suatu potensi yang dimiliki anak agar menjadi manusia yang beriman, berakhlak mulia, berilmu, dan bertanggung jawab dalam segala hal. Keberhasilan pembelajaran seorang siswa itu sendiri memiliki arti yaitu dengan cara mencari atau menerima informasi dengan menghafal, mengamati, memahami, dan melakukan dengan caranya sendiri sehingga terwujudlah perubahan pada diri seseorang.

Namun pada saat ini Indonesia diserang oleh wabah virus penyakit yang mematikan yang melanda seluruh duniasebagai bencana non-alam yakni covid-19 yang disebabkan oleh virus Corona atau Severe acute respiratory syndrome coronavirus 2 (SAS-Cov-2). Wabah ini berasal dari Wuhan, Provinsi Hubai China yang kemudian secara perlahan menyebar ke seluruh dunia dengan nama 2019-nCoV. Penyebaran covid-19 selama kurun waktu Desember 2019-Februari 2020 tidak ada kasus infeksi, namun pada tanggal 2 Maret 2020 dua kasus pertama terkonfirmasi infeksi covid-19.

Kebijakan pemerintah untuk menanggulagi penyebaran covid-19 diantaranya pembatasan aktivitas, himbauan selalu untuk menjaga kebersihan diri, social distancing, physical distanching, karantina wilayah, bekerja di rumah bagi karyawan, hingga pembatasan mobilitas manusia dari wilayah ke wilayah lain. Adanya covid-19 juga menuntut adanya perubahan dalam pembelajaran. Hal ini turut dilakukan oleh beberapa wilayah di Indonesia untuk mencegah penyebaran covid-19, salah satunya di Provinsi Jwa Timur. Surat edaran Gubernur Jawa Timur Nomor 420/5952/436.7.1/2020 perihal meningkatkan kewaspadaan terhadap covid-19, Gubernur telah menetapkan 16 butir yang harus diperhatikan salah satunya yaitu pelaksanaan proses pembelajaran dalam jaringan (daring) atau belajar dirumah. Walikota Surabaya juga mengeluarkan Surat Edaran Nomor 360/3324/436.8.4/2020 perihal meningkatkan kewaspadaan covid-19 di surabaya yang salah satunya memberlakukan pembelajran jarak jauh (PJJ) atau belajar dari rumah bagi peserta didik pada satuan pendidikan (PIAUD/TK, SD, SMP). Program

\footnotetext{
${ }^{1}$ Sanjaya, Wina. 2006. Strategi Pembelajaran Berorientasi Standar Proses Pendidikan. Jakarrta: Kencana
} 
belajar dari rumah dilaksanakan secara mandiri di rumah masing-masing. Adanya kebijakan tersebut membuat orang tua kembali lagi menguatkan perannya untuk menjadi pendidik pertama dan utama bagi anak. ${ }^{2}$

Orang tua merupakan penanggung jawab utama dalam pendidikan anak-naknya. Dimanapun anak menjalani pendidikan, baik dilembaga formal, informal maupun non formal orang tua tetap berperan dalam menentukan masadepan pendidikan anak-anaknya. Pendidikan di luar keluarga, bukan dalam arti melepaskan tanggung jawab orang tua, tetapi hal itu dilakukan orang tua semata-mata karena keterbatasan ilmu yang dimiliki oleh orang tua, karena sifat ilmu yang terus berkembang mengikuti perkembangan zamannya, sementara orang tua memiliki keterbatasan-keterbatasan. Disamping itu orang tua juga, orang tua memiliki kesibukan bekerja untuk memenuhi kebutuhan keluarga, ikut mendorong orang tua untuk meminta bantuan pihak lain dalam pendidikan anaknya.

Sehubungan dengan hal tersebut, salah satu masalah yang dihadapi dunia pendidikan adalah masalahnya proses pembelajaran pada masa pandemi. Dalam proses pembelajaran berlangsung yang diselenggarakan dirumah pada masa pandemi covid-19 siswa tidak begitu optimal karena anak kurangnya atas dorongan dari orang tua untuk mengembangakan kemampuan berfikir. Ini menjadi tantangan bagi orang tua dalam perannya sebagai pengganti seorang guru.

Dalam hal ini orang tua sangatlah penting berperan dalam proses kegiatan pembelajaran berlangsung yang diselenggarakan di rumah pada masa pandmi covid-19 pada saat ini agar proses kegiatan pembelajaran tetap normal dan bisa efektif.

Pandemi covid-19 juga telah berdampak pada Desa Kumpulrejo Kecamatan Parengan Kabupaten Tuban. Masyarakat Desa Kumpulrejo sebagian ada yang takut dan ada yang tidak takut dengan adanya covid-19. ${ }^{3}$

Dengan adanya covid-19 Kepala Desa Kumpulrejo mengikuti peraturan pemerintah untuk tidak melakukan kegiatan yang sifanya bergerombolan atau berkerumunan dan menganjurkan untuk selalu cuci tangan dan memakai masker. Covid-19 juga berdampak pada pembelajran anak

\footnotetext{
${ }^{2}$ Widiswaro, Erwin. 2017. Inovasi Pembelajaran Berbasis Life Skill \& Enterpreneurship. Yogyakarta:Ar-Ruzz media.

${ }^{3}$ Winarno. 2020. Covid-19 Pelajaran Yang Berharga Dari Sebuah Pandemic. Jakarta : PT. Gramedia Pustaka Utama.
} 
sekolah khususnya dalam proses kegiatan pembelajaran anak SMP Desa Kumpulrejo dilakukan secara Daring atau dilakukan dirumah PJJ (Pembelajaran Jarak Jauh).

Pembelajaran anak SMP dilakukan secara dirumah pastinya akan melibatkan orang tua untuk berperan sebagai guru. Tetapi banyak orang tua anak SMP Desa Kumpulrejo yang kurangnya pengetahuan. Karena mayoritas orang tua mereka hanya lulusa SD. Untuk itu mereka hanya berperan sebagai pendukung dan mengingatkan terhadap anaknya untuk selalu belajar giat dan bersungguh-sungguh walau pembelajaran dilakukan di rumah.

Berdasarkan pra survey yang dilakukan oleh peneliti di desa Kumpulrejo Kecamatan Parengan Kabupaten Tuban melalui wawancara dan observasi untuk mendapatkan informasi dengan cara mewancarai beberapa siswa SMP beserta orang tuanya disekitar desa Kumpulrejo. Berkaitan dengan hal tersebut, peneliti tertarik meneliti lebih lanjut tentang peran orang tua dalam proses kegiatan pembelajaran siswa dalam masa pandemi covid-19, yang dapat menjadi salah satu referensi untuk mengetahui bagaimana proses pembelajaran dimasa pandemi dalam dunia pendidikan pada saat ini. Untuk itu peneliti mengangkat dalam sebuah penelitian dengan rumusan masalah dibawah ini : 1. Bagaimana peran orang tua dalam mendukung kegiatan pembelajaran anak SMP di rumah pada masa pandemi covid-19 di Desa Kumpulrejo Kecamatan Parengan Kabupaten Tuban Tahun Pelajaran 2020/2021? 2. Bagaimana faktor penghambat dan pendukung kegiatan pembelajaran anak SMP di rumah pada masa pandemi covid-19 di Desa Kumpulrejo Kecamatan Parengan Kabupaten Tuban Tahun Pelajaran 2020/2021 ? Berdasarkan hasil dari rumusan masalah di atas, maka tujuan peneliti ini adalah sebagai berikut: 1 . Untuk mengetahui peran orang tua dalam mendukung kegiatan pembelajaran anak SMP di rumah pada masa pandemi covid-19 di Desa Kumpulrejo Kecamatan Parengan Kabupaten Tuban tahun pelajaran 2020/2021. 2. Untuk mengetahui faktor penghambat dan pendukung kegiatan pembelajaran anak SMP di rumah pada masa pandemi covid-19 di Desa Kumpulrejo Kecamatan Parengan Kabupaten Tuban Tahun Pelajaran 2020/2021.

\section{Metodologi}

Pendekatan yang digunakan dalam penelitian ini adalah pendekatan kualitatif, yaitu suatu pendekatan penelitian yang menghasilkan penemuan-penemuan yang tidak dapat diukur dengan menggunakan prosedur-prosedur statistik dengan cara kuantifikasi (pengukuran). Sebagaimana menurut Bogdan dan Taylor mendefinisikan metodologi kualitatif sebagai prosedur penelitian 
yang menghasilkan data deskriptif berupa kata-kata tertulis atau lisan dari orang-orang dan

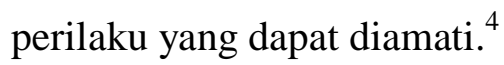

Hal ini digunakan untuk memaparkan atau menggambarkan fakta, sifat, serta hubungan antar fenomena yang di selidiki baik berupa tulisan atau kata-kata kemudian dilakukan pengkajian atau analisa.

Sedangkan penelitian ini, menggunakan jenis penelitian deskriptif. Penelitian deskriptif merupakan penelitian terhadap fenomena atau populasi tertentu yang diperoleh peneliti dari subjek berupa individu, organisasi, industri atau perspektif yang lain. Adapun tujuannya adalah untuk menjelaskan aspek-aspek yang relevan dengan fenomena yang diamati, menjelaskan karakteristik fenomena atau masalah yang ada. Pada umumnya penelitian deskriptif ini tidak perlu merumuskan tindakan hipotesis. dalam bukunya penelitian deskriptif data yang dikumpulkan adalah berupa kata-kata, gambar, dan bukan angka-angka. Hal itu disebabkan oleh adanya penerapan metode kualitatif. Selain itu, semua yang dikumpulkan berkemungkinan menjadi kunci terhadap apa yang sudah diteliti.

Dengan demikian, laporan penelitian akan berisi kutipan-kutipan data untuk memberi gambaran penyajian laporan tersebut. Data tersebut mungkin berasal dari naskah wawancara, catatan lapangan, foto, videotape, dokumen pribadi, catatan atau memo, dan dokumen resmi lainnya. ${ }^{5}$

Berdasarkan sifat penelitian diatas, maka dalam penelitian ini peneliti akan berupaya mendiskripsikan secara sistematis mengenai peran orang tua dalam mendukung kegiatan pembelajaran anak SMP di rumah pada masa pandemi covid-19 di Desa Kumpulrejo Kecamatan Parengan Kabupaten Tuban tahun pelajaran 2020-2021, didasarkan pada data-data yang terkumpul selama penelitian dan dituangkan dalam bentuk laporan dan uraian. Adapun lokasi yang di gunakan untuk penelitian dalam skripsi ini adalah siswa SMP beserta orang tuanya di Desa Kumpulrejo Kecamatan Parengan Kabupaten Tuban. Penelitian ini dilakukan pada saat proses kegiatan pembelajaran Daring anak SMP dirumahnya masing-masing pada masa pandemi Covid-19 di Desa Kumpulrejo Kecamatan Parengan Kabupaten Tuban. Alasan peneliti memilih lokasi penelitian di Desa Kumpulrejo Kecamatan Parengan Kabupaten Tuban ini dikarenakan kembanyakan orang tua wali anak SMP kurangnya pengetahuan tentang pembelajaran Daring.

\footnotetext{
${ }^{4}$ Moleong, Lexy J. 2019. Metodologi Penelitian Kualitatif. Bandung: PT. Remaja Rosdakarya.

${ }^{5}$ Moleong, Lexy J. 2019. Metodologi Penelitian Kualitatif. Bandung: PT. Remaja Rosdakarya.
} 


\section{Hasil}

Pada bagian ini peneliti akan menguraikan data yang diperoleh dari hasil wawancara, dan disini peneliti merupakan instrumen kunci dalam penelitian kualitatif disini peneliti menggunakan instrumen penelitian observasi, wawancara, dan dokumentasi untuk melaksanakan penelitiannya. Dengan wawancara peneliti dapat mengetahui tentang uraikan pelaksanaan peran orang tua dalam mendukung kegiatan pembelajaran anak SMP di rumah pada masa pandemi covid-19 di Desa Kumpulrejo Kecamatan Parengan Kabupaten Tuban.

Peran orang tua dalam mendukung kegiatan pembelajaran anak pada masa pandemi covid19 sangatlah penting, terutama untuk prestasi dan semangat belajar selama pembelajar di rumah. Selanjutnya berdasarkan data-data yang sudah diperoleh peneliti, maka peneliti akan menganalisi data tersebut, guna untuk memperjelas agar lebih mudah untuk dipahami oleh semua pembaca.

Berdasarkan hasil penelitian yang dilakukan melalui wawancara dengan salah satu Perangkat Desa Kumpulrejo, yaitu Bapak Amin yang ditemui di rumahnya pada hari minggu pukul 15.05 tanggal 07 Maret 2021.

"Orang tua mempunyai peran yang sangat penting dalam penerapan pendidikan anaknya. Orang tua sebagai pendidik utama bagi anak-anaknya, maka dari itu orang tua harus memberikan contoh yang baik pada anaknya. sudah jelaskan ya mbk?, bahwa peran orang tua sangatlah penting dalam menerapkan pendidikan anaknya. Pada saat ini dengan adanya wabah virus yang menakutkan nek coro jowone wayah pagebluk atau paceklik yang ditakuti seтиa masyarakat Indonesia, maka dari itu proses kegiatan pembelajran anak dilakukan di rumah secara online dan orang tualah akan menggantikan peran guru ketika pembelajaran di rumah. Dalam hal ini peran orang tua dalam mendukung kegiatan pembelajaran anak pada masa pandemi saat ini yaitu dengan secara kita memberi dorongan kepada anak untuk belajar. Kareana dorongan orang tua sangatlah penting dan sangat berpengaruh bagi anak terutama anak SMP yang sedang menginjak remaja".

Dari keterangan Pak Amin selaku perangkat Desa menjabat sebagai kaur perencanaan Desa Kumpulrejo ini dapat disimpulkan bahwa peran orang tua dalam pembelajaran anak di rumah pada masa pandemi sangatlah penting, diantarannya peran orang tua dalam mendukung kegiatan pembelajaran anak SMP di Desa Kumpulrejo pada masa pandemi covid-19 yaitu selalu 
memberikan dorongan atau dukungan pada diri anak untuk selalu mengikuti bembelajaran yang dilakukan secara daring.

Dari hasil wawancara 2 dengan ibu Martini selaku orang tua anak SMP di Desa Kumpulrejo. Pada hari minggu pukul 16.30 tanggal 07 Maret 2021. Jawaban yang di berikan dari Ibu Martini berikan hampir sama dengan hasil wawancara pertama dari Pak Amin, beliau mengemukakan,

"Orang tua sangatlah penting untuk berperan sebagai pendukung anak dalam pembelajaran. Peran saya sebagai orang tua dalam mendukukung kegiatan pembelajaran anak saya yaitu dengan cara memberikan semangat terhadap anak saya untuk selalu belajar yang rajin walaupun pembelajarannya dilakukan secara online dan ketika saya tidak sibuk saya juga ikut serta dalam proses pembelajaran anak saya, misalnya dengan membantu anak saya jika tidak memahami materi yang diberikan gurunya ".

Dari keterangan Ibu Martini seorang pekerja sebagai petani dan sebagai ibu rumah tangga beliau selaku orang tua anak SMP. Jawaban yang disampaikan Ibu Martini dapat disimpulkan bahwa semangat dari orang tua juga sangat penting bagi diri anak. Karena dengan adanya semangat dari orang tua bisa membantu anak untuk meningkatkan semangat belajar anak.

Dari hasil wawancara 3 dengan bapak Suwoto sebagai orang tua anak SMP di Desa Kumpulrejo. Pada hari minggu pukul 19.10 tanggal 07 Maret 2021. Jawaban yang beliau berikan itu berbeda dari hasi pada saat wawancara ke 1 dan ke 2.

"Peran saya sebagai orang tua dalam proses pembelajaran, saya hanya memenuhi fasilitas yang dibutuhkan anak saya dalam pembelajaran daring, sedangkan dalam proses pembelajaran saya kembalikan kepada anak dan guru yang mengajarnya”.

Keterangan dari Pak Suwoto dapat disimpulkan bahwa peran orang tua yang dilakukan beliau hanya memenuhi fasilitas anak dalam pembelajaran di rumah pada masa pandemi covid19. Karena beliau sangat sibuk dengan pekerjaannya sebagai petani begitupun juga istrinya juga sibuk dengan kesehariannya sebagai petani dan pekerjaan lainnya.

Dari hasil wawancara 4 dengan ibu Wasi selaku orang tua anak SMP di Desa Kumpulrejo. Pada hari minggu pukul 19.20 tanggal 08 Maret 2021. Jawaban yang diberikan oleh ibu wasi itu saagat berbeda dari dari hasil wawancara yang sebelumnya. 
"Peran saya sebagai orang tua saya merasa kesulitan dalam sekolah daring pada saat ini dikarenakan ekonomi yang tidak memungkinkan untuk membelikan fasilitas seperti $h p$, dan kebutuhan daring lainnya. Sementara itu saya hanya bisa meminjamkan $h p$ tetangngga untuk bisa mengikuti kelas daring dan meminta tolong tetangga untuk mengajari anak saya dalam proses pembelajaran daring".

Dari keterangan Ibu Wasi ini dapat disimpulkan bahwa peran orang tua yang dialami Ibu Wasi dalam pembelajran dirumah saat ini sangat sulit karena kurangnya ilmu pengetahuan dimiliki, beliau hanya lulusan dari SD saja itupun tidak sampai lulus sekolah dan keadaan ekonominya kurang baik. Pekerjaan beliau kesehari-hari hanyalah seorang buruh tani biasa mereka tidak memiliki sawah sendiri.

Dalam proses kegiatan pembelajaran yang dilakukan secara daring beliau mengikutkan anaknya ketetangga untuk bisa mengikuti pembelajaran yang dilakukan secara daring. Peran Ibu Wasi hanya mengikutkan anaknya kepada tetangganya untuk membantu anaknya dalam proses pembelajaran yang dilakukan di rumah secara daring.

Selanjutnya hasil wawancara dengan ibu Sureni Rahayu sebagai orang tua anak SMP di Desa Kumpulrejo. Pada hari Senin pukul 08.26 tanggal 19 April 2021.

"Peran orang tua dalam mendukung kegiatan pembelajaran anak saya di rumah pada masa pandemi covid-19 peran saya yaitu ikut memantau ketika jam pelajaran sedang dimulai. Karena jika saya tidak ikut memantau terkadang anak saya malas dalam proses bempelajaran daring yang sedang dimulai dan minat belajar anak akan kurang, untuk itu saya ikut serta dalam proses pembelajaran anak saya dan ikut berpatisipasi dalam proses bembelajaran yang dilakukan secara daring".

Dari hasil responden wawancara dan observasi oleh orang tua diatas dapat disimpulkan bahwa peran orang tua itu sangat berpengaruh bagi anak dalam kegiatan pembelajaran, terutama pada anak SMP. Karena orang tua merupakan pendidik pertama bagi anak-anaknya, selain itu orang tua adalah orang yang dipercaya oleh anak untuk membimbingnya, memberikan arahan, dan memberikan kasih sayang yang tulus bagi anak.

Peran orang tua dalam memberikan dukungan dalam proses kegiatan pembelajaran di rumah pada masa pandemi sangat penting untuk meningkatkan semangat belajar pada anak, selain itu keterlibatan orang tua dan perhatian orang tua terhadap anak itu dapat menimbulkan psikologis yang bagus bagi diri anaknya dan hasil belajar anakpun akan menjadi lebih baik. 
Orang tua juga harus memberikan contoh sikap baik terhadap anaknya selama anaknya belajar dirumah, supaya anak tidak bosan ketika belajar selama masa pandemi.

Selanjutnya responden dari anak SMP desa Kumpulrejo hasil wawancara dari adek Julia Sriyani Dwiyanti siswi SPM 2 Parengan pukul 17.00 tanggal 07 Maret 2021.

"Pada saat pembelajaran daring ibu saya perberan dengan cara selalu memberi semangat. Karena semangat dari ibu saya sangat penting bagi saya, ibu sering mengingatkan saya untuk selalu belajar dan ibu selalu memberi paket data internet saya selama belajar dirumah pada masa pandemi covid-19. Dan ibu saya juga berperan sebagai seperti guru ketika saya tidak bisa memahami materi yang diberikan dari guru”.

Selanjutnya responden dari anak SMP desa Kumpulrejo hasil wawancara dari adek Dimas Andika Putra siswa SPM 2 Parengan pukul 19.58 tanggal 07 Maret 2021.

"Peran orang tua saya pada pembelajaran daring pada masa pandemi saat ini hanya memberikan fasilitas HP dan data internet saja Karena orang tua saya sibuk disawah dan orang tua saya hanyalah lulusan SD itupun tidak sampai lulus maka dari itu orang tua saya tidak faham sama sekali tentang pelajaran sekolah. Tetapi terkadang juga mengingatkan saya untuk belajar".

Selanjutnya responden dari anak SMP desa Kumpulrejo hasil wawancara dari adek Dita Dwi Lestari siswi SPM 2 Parengan pukul 20.00 tanggal 08 Maret 2021.

"Dalam proses kegiatan pembelajaran di rumah pada masa pandemi saat ini mungkin akan menyenangkan jika orang tua saya terlibat dalam hal ini, tetapi sayangnya kondisi orang tua saya yang selalu bekerja dan tidak adanya fasilitas seperti HP atau laptop jadi saya merasa ini sangat sulit untuk saya lalui. Tetapi saya tidak pernah putus asa dalam proses kegiatan belajar daring, pada saat pembelajaran daring dimulai saya meminta tolong kerumah tetangga saya untuk meminjam HP dan data internetnya untuk saya pergunakan dalam pembelajaran daring dan jika ada materi pelajaran yang saya tidak bisa memahami saya bertanya sama tetangga saya yang meminjami HP ".

Selanjutnya responden dari anak SMP desa Kumpulrejo hasil wawancara dari adek Heny Fransiska Putri SPM 2 Parengan pukul 13.30 tanggal 19 April 2021.

"Peran orang tua sangat penting, orang tua harus mendampingi anaknya pada saat pembelajaran daring berlangsung. Orang tua harus mengecek anaknya apakah anaknya 
itu benar-benar mengikuti proses kegiatan pembelajaran yang dilakukan dirumah secara daring atau tidak?."

Dari hasil wawancara dari sebagaian siswa dan siswi SMP desa Kumpulrejo Parengan Tuban menunjukan bahwasanya peran orang tua dalam mendukung kegiatan pembelajaran anak pada masa pandemi itu sekarang sangat berpengaruh pada anak, jika tidak adanya dukungan atau dorongan dari orang tua seorang siswa akan malas untuk belajar. Maka peneliti menemukan dari hasil wawancara yaitu peran orang tua selain memberikan dorongan pada anaknya orang tua juga memberi fasilitas yang dibutuhkan anaknya dalam pembelajaran online.

Dari observasi dan wawancara peneliti terhadap orang tua anak SMP dan siswa-siswi SMP di Desa Kumpulrejo Kecamatan Parengan Kabupaten Tuban ada beberapa faktor yaitu, baik faktor penghambat dan faktor pendukung dalam proses kegiatan pembelajaran anak SMP di rumah pada masa pandemi covid-19.

Dari hasil wawancara dengan ibu Martini selaku orang tua anak SMP di Desa Kumpulrejo. Pada hari minggu pukul 16.30 tanggal 07 Maret 2021. Beliau mengatakan:

"Pada saat pembelajaran anak pada saat masa pandemi ini yang menjadi yang faktor penghambat adalah sering terkendala signal yang kurang baik sehingga anak saya kurang semangat untuk mengikuti pembelajaran daring. Faktor yang menjadi pendukung dalam pembelajaran anak selama di rumah pada masa pandemi saya sebagai orang tua, alhamdulillah saya bisa memfasilitasi peralatan pembelajaran yang dibutuhkan anak saya pada masa pandemi ini seperti memfasilitasi HP, memberikan paket data internet walaupun tidak banyak dan saya terkadang juga membantu anak saya ketika anak saya tidak mengerti materi yang diajarkan gurunya jika saya bisa”.

Selanjutnya dari hasil wawancara dengan bapak Suwoto sebagai orang tua anak SMP di Desa Kumpulrejo. Pada hari minggu pukul 19.10 tanggal 07 Maret 2021.

"Faktor penghambat yang sering dialami anak saya dalam proses pembelajaran anak saya yaitu kurang fahamnya materi yang diajarkan gurunya dan saya tidak bisa membantunya karena lemahnya pengetahuan saya (ketol) maka dari itu terkadang anak saya belajar bareng sama temannya. Faktor yang menjadi pendukung pembelajaran pada masa pandemi yaitu saya bisa memberikan fasilitas seperti HP, dan uang untuk membeli paket data internet”. 
Selanjutnya dari hasil wawancara dengan ibu Wasi selaku orang tua anak SMP di Desa Kumpulrejo. Pada hari minggu pukul 19.20 tanggal 08 Maret 2021.

"Pada saat adanya covid-19 ini saya menjadi merasa kebingungan kareana pembelajaran dilakukan di rumah itu membutuhkan fasilitas HP, dan paket data internet, saya merasa kasihan terhadap anak saya karena saya tidak bisa memenuhi kebutuhan fasilitas seperti membelikan hp dan memberi paket data internet yang dibutuhkan oleh anak saya kareana dengan keadaan ekonomi saya yang kurang. Karena saya hanya buruh tani biasa saja untuk itu saya tidak bisa memenuhi kebutuhan peralatan yang digunakan pembelajaran anak saya pada masa pandemi”.

Selanjutnya dari hasil wawancara dengan ibu Sureni Rahayu sebagai orang tua anak SMP di Desa Kumpulrejo. Pada hari Senin pukul 08.26 tanggal 19 April 2021.

"Yang menjadi faktor penghambat dari pembelajaran daring yang dilakukan di rumah pada masa pandemi ini adalah guru tidak bisa menjelaskan materi secara langsung sehingga siswa kurang paham tentang materi yang diberikan, faktor ekonomi yang cukup, minat belajar pada siswa berkurang kareana guru tidak tepat waktu dalam membuka kelas online. Adapun yang menjadi faktor pendukung yaitu terpenuhinya fasilitas seperti: HP, kuota internet, dan buku pelajaran bagi siswa. Fasilitas tersebut akan menambah kesemangatan bagi siswa untuk belajar”.

Dari hasil wawancara dan observasi diatas dapat disimpulkan bahwa dalam proses kegiatan pembelajaran anak SMP di rumah pada masa pandemi covid-19 tidak semua dapat berjalan lancar sesuai dengan tujuan yang diinginkan oleh guru, orang tua dan anak SMP. Karena ada faktor yang menjadi penghambat proses kegiatan pembelajaran di rumah adalah kurangnya jangkauan signal yang kuat akan mengakibatkan siswa kurang bersemangat dalam belajar yang dilakukan secara daring sehingga proses pembelajaran tidak bisa maksimal, dan ada lagi faktor yang menjadi penghambat pembelajaran anak SMP Desa Kumpulrejo yang dilakukan dirumah secara daring yaitu guru tidak bisa menyampaikan materi secara langsung. Hal tersebut akan mengakibatkan siswa akan merasa bosan dan akan menimbulkan sifat malas pada siswa karena guru hanya menyampaikan materi pelajaran lewat online.

Selain faktor penghambat ada juga faktor pendukung yang akan meningkatkan semangat pada diri siswa untuk melakukan kegiatan pembelajaran yang dilakukan di rumah secara daring. Faktor yang menjadi pendukung kegiatan pembelajaran anak SMP di rumah pada masa pandemi 
covid-19 adalah orang tua selalu memberikan semangat pada anaknya sehingga akan menumbuhkan rasa semangat untuk belajar secara daring yang dilakukan dirumah, selain itu ada lagi yang menjadi faktor pendukung dalam kegiatan pembelajaran anak SMP di rumah yaitu dengan terpenuhi fasilitas anak SMP Desa Kumpulrejo yang dibutuhkan pada saat pembelajaran daring diantaranya seperti HP yang ber android, paket data internet.

Selanjutnya responden dari anak SMP desa Kumpulrejo hasil wawancara dari adek Julia Sriyani Dwiyanti siswi SPM 2 Parengan pukul 17.00 tanggal 07 Maret 2021.

"Faktor yang menjadi penghambat saya dalam proses kegiatan pembelajaran daring adalah kurangnya memahami materi pembelajaran yang diberikan oleh guru secara online. Karena guru tidak bisa semaksimal mungkin untuk bisa menyampaikan materi secara online. Dan yang menjadikan saya semangat untuk belajar dengan adanya faktor pendukungnya yaitu orang tua saya bisa meberikan fasilitas yang saya butuhkan pada saat pembelajaran daring".

Selanjutnya responden dari anak SMP desa Kumpulrejo hasil wawancara dari adek Dimas Andika Putra siswa SPM 2 Parengan pukul 19.58 tanggal 07 Maret 2021.

"Adapun yang menjadi salah satu faktor penghambat pada saat pembelajaran daring yaitu saya kurangnya bisa memahami materi karena pembelajaran daring tidak bisa efektif untuk itu terkadang saya belajar bergabung dengan teman saya untuk belajar bersama. Yang menjadi pendukung saya pada pembelajaran masa pandemi saat ini adalah orang tua saya, karena orang tua saya bisa memenuhi kebutuhan fasilitas yang saya butuhkan pada saat pembelajaran daring. Diantaranya fasilitas yang diberikan orang tua saya yaitu dengan membelikan HP baru dan memberikan uang syaa untuk membeli paket data internet".

Selanjutnya responden dari anak SMP desa Kumpulrejo hasil wawancara dari adek Dita Dwi Lestari siswi SPM 2 Parengan pukul 20.00 tanggal 08 Maret 2021.

"Faktor yang menjadi penghambat saya dalam pembelajaran di rumah pada masa pandemi saat ini yaitu saya tidak memiliki HP untuk digunakan belajar daring. Pada saat pembelajaran daring dimuali saya ikut belajar dengan teman saya yang memiliki hp terkadang juga meminjam HP tetangga dekat rumah karena orang tua tidak mampu untuk membelikan HP". 
Selanjutnya responden dari anak SMP desa Kumpulrejo hasil wawancara dari adek Heny Fransiska Putri SPM 2 Parengan pukul 13.30 tanggal 19 April 2021.

"Faktor yang menjadi penghambat pada saat pembelajaran daring yang dilakukan dirumah yaitu dikarenakan saya kurangnya bisa memahami materi, keterlambatan oleh signal karena rumah saya berada didataran tinggi, dan keterbatatasan kuota internet. Adapun faktor yang menjadi pendukung pada saat pembelajaran di rumah yaitu orang tua saya selalu memberi dukungan atau semangat kepada saya untuk selalu rajin belajar walaupun pembelajarannya dilakukan secara daring. Faktor pendukung yang menjadikan saya semangat untuk belajar yaitu dengan fasilitas yang ada seperti hp dan data internet walaupun keadaan signalnya lambat".

Dalam proses kegiatan pembelejaran daring pada siswa SMP yang dilakukan secara di rumah tidak semua bisa berjalan dengan baik sesuai harapan orang tua dan guru, karena ada beberapa faktor yang menjadi penghambat dalam proses pembelajaran daring yang dialami anak SMP di rumah pada masa pandemi di Desa Kumpulrejo yaitu kurangnya maksimal dalam belajar dikarenakan pada saat guru menyampaikan materi secara online karena terkendala signal yang tidak terjangkau. Hal tersebut akan mengakibatkan anak SMP Desa Kumpulrejo akan malas untuk mengikuti pembelajaran yang dilakukan secara daring. Kebanyakan siswa mengikuti pembelajaran daring tetapi tidak dengan semangat melainkan siswa mengikuti pembelajaran dengan cara seenaknya sendiri.

Namun ada faktor yang menjadi pendukung untuk memperlancar pelaksanaan pembelajaran yang dilakukan secara dirumah yaitu dengan adanya dukungan untuk belajar dari orang tua, terpenuhinya fasilitas yang memadahi, buku pegangan siswa dari sekolahan, ekonomi yang tercukupi.

Peran orang tua dalam mendukung kegiatan pembelajaran anak SMP di rumah pada masa pandemi covid-19 itu sangat penting, karena orang tua termasuk madrasah atau pendidik pertama bagi anaknya. Orang tua merupakan pendidikan pertama bagi anaknya, oleh sebab itu orang tua harus mengerti akan perannya sebagai orang tua dapat melaksanakan kewajiban sebagai orang tua dan memberikan hak anak sesuai kaidahnya. Dalam hal ini, orang tua dapat memberikan dorongan, kasih sayang, perhatian, dan membimbing anaknya untuk rajin belajar serta menghasilkan nilai yang baik untuk anaknya. 
Dalam keadaan masa pandemi covid-19 pada saat ini, orang tua juga harus bijak dalam menyikapinya karena sikap orang tua berdampak pada anaknya sendiri. Orang tua diharapkan dapat memberikan pengertian akan adanya masa pandemi covid-19 saat ini kepada anaknya. Dalam proses pembelajaran anak SMP Desa Kumpulrejo pada saat pandemi ini peran orang tua sangat dibutuhkan untuk anaknya dalam proses pembelajaran yang dilakukan di rumah. Peran orang tua dalam proses pembelajaran di rumah pada masa pandemi ini orang tua sementara menggantikan peran guru yang ada disekolah.

Berdasarkan hasil penelitian, dapat ditemukan bahwasannya peran orang tua dalam mendukung kegiatan pembelajaran anak SMP di rumah pada masa pandemi covid-19 tersebut dapat diklarifikasikan ke dalam tiga macam peran orang tua diantaranya yaitu:

1. Memberikan motivasi dan memberi semangat pada anak

Orang tua harus mampu memberikan motivasi dan memberikan semangat untuk belajar pada anaknya, agar pada saat proses pemebalajaran daring yang dilakukan dirumah akan lebih rajin dan semangat. Dalam keadaan pada masa pandemi covid-19 ini motivasi orang tua sangat penting bagi anaknya, jika tidak adanya motivasi dan semangat dari orang tua kegiatan pembelajaran anak akan terhambat.

2. Orang tua sebagai fasilitator pada anak

Selain memberikan motivasi dan memberikan semangan diri pada anak orang tua juga berperan sebagai fasilitator pada proses pembelajaran yang dilakukan anak pada saat masa pandemi covid-19 ini. Peran orang tua anak SMP Desa Kumpulrejo ada yang hanya sebagai fasilitator saja, cukup memberikan kebutuhan bagi anaknya dalam proses pembelajaran segi materi saja. Dikatakan cukup karena orang tua sudah melakukan perannya sebagai fasilitator, akan tetapi peran yang dilakukan oleh orang tua pada saat pembelajaran yang dilakukan secara di rumah kepada anaknya hanya sebatas memenuhi kebutuhan fasilitas yang dibutuhkan anak untuk pembelajaran online. Akan tetapi ada juga orang tua yang mampu memfasilitasi anak dalam segi pengetahuan tentang materi pelajaran jika anaknya tidak bisa memahami materi pelajaran yang disampaikan guru.

Fasilitas yang dapat dipenuhi orang tua dalam proses pembelajaran daring diantaranya yaitu:

1. Membelikan HP android

Jika orang tua membelikan HP android, anak dapat mengikuti pembelajaran secara online. Akan tetapi bila orang tua tidak bisa memlikan HP proses pembelajaran anak akan 
terhambat. Karena HP termasuk alat media penting untuk pembelajaran yang dilakukan secara daring. Karena HP android tersebut akan dipergunakan siswa untuk membantu mengakses informasi dalam menyelesaikan tugasnya yang diberikan oleh guru secara online.

2. Kuota Internet

Pembelajaran daring tidak lepas dari jaringan internet. Untuk melakukan pembelajaran secara daring atau online seperti saat ini, tentunya sangat diperlukan jaringan internet. Dengan orang tua membelikan kuota internet anaknya bisa mengikuti pembelajaran yang dilakukan secara daring. Karena untuk mengikuti pemebelajaran yang dilakukan secara daring dan digunakan untuk mengirim tugas yang diberikan oleh guru.

3. Mengawasi anak dalam belajar

Selama ada kebijakan belajar dari rumah orang tua diharapkan untuk selalu mengawasi anaknya dalam belajar yang dilakukan secara daring. Peran orang tua sebagai pengawas itu juga sangat penting bagi anaknya dalam proses pembelajaran. Orang tua berperan sebagai pengawas dalam pembelajaran anaknya misalnya orang tua harus mengawasi gerak anak proses pembelajaran apakah anaknya benar-benar mengikuti pembelajaran daring atau hanya berpura-pura mengikuti pembelajaran daring. Selain itu orang tua juga harus mengingatkan anaknya bahwasannya sekarang sudah waktunya pembelajaran daring dimulai dan mengingatkan anak apakah sudah mengerjakan tugas atau belum.

Tetapi sebagian orang tua anak SMP di Desa Kumpulrejo tidak bisa mengawasi anak dalam proses pembelajaran daring yang dilakukan di rumah, dikarenakan mereka mempunyai kesibukan sendiri yaitu kesibukan dalam pekerjaan. Sehingga orang tua mereka tidak bisa membagi waktu untuk mengawasi anaknya dalam proses kegiatan pembelajaran yang dilakukan di rumah secara daring.

Dari paparan di atas sesuai dengan teori. Diantara peran orang tua dalam proses pembelajaran dirumah pada masa pandemi covid-19 yaitu menjaga motivasi anak, memfasilitasi anak, menumbuhkan kreatifitas anak, mengawasi anak dalam belajar, mengevaluasi hasil belajar anak. ${ }^{6}$

\footnotetext{
${ }^{6}$ Sudarsana, Ketut dkk. 2020. Covid-19:Perspektif Pendidikan. Jakarta: Yayasan Kita Menulis.
} 
Faktor Penghambat Dan Pendukung Kegiatan Pembelajaran Anak SMP Di Rumah Pada Masa Pandemi Covid-19 Di Desa Kumpulrejo Kecamatan Parengan Kabupaten Tuban Tahun Pelajaran 2020/2021

Dari hasil wawancara diatas adalah penjelasan dari faktor penghambat dan pendukung proses kegiatan pembelajaran anak pada masa pandemi covid-19. Dalam proses pembelajaran tidak akan tertinggal dari suatu faktor yakni faktor penghambat dan pendukung.

1. Faktor Penghambat

Dalam proses pembelajaran daring atau pembelajaran di rumah ada sebuah faktor yang menjadi penghambatnya yang dihadapi baik oleh pengajar atau pembelajar dari pemberlakuan pembelajaran daring selama masa pandemi diantaran yaitu: koneksi internet yang kurang, kurang paham dalam menggunakan teknologi, susah mengukur pemahaman siswa, standarisasi dan efektivitas pembelajaran, kurangnya interaksi dalam pembelajaran. ${ }^{7}$

Faktor penghambat merupakan suatu hal yang terjadi kendala untuk mencapai tujuan. Pada proses kegiatan pembelajaran anak SMP di Desa Kumpulrejo Kecamatan Parenagan Kabupaten Tuban yang dilakukan secara daring ada beberapa hal yang menjadi penghambat dalam pembelajaran yang dilakukan di rumah yakni:

a. Kurangnya pengetahuan orang tua

Kurangnya pengetahuan dapat menjadi salah satu penghambat dalam proses pembelajaran anaknya. Mayoritas pendidikan orang tua anak SMP di Desa Kumpulrejo itu hanya sampai sekolah dasar (SD) itupun juga ada yang tidak sampai lulus. Ketika anaknya tidak bisa memahami materi yang disampaikan oleh guru lewat online, anak tidak dapat bertanya tentang materi yang tidak bisa di pahami kepada orang tua, dikarenakan minimnya pengetahuan yang dimiliki oleh orang tua.

b. Sulit memahami materi

Siswa SMP Didesa kumpulrejo pada saat proses pembelajaran daring mereka akan kesulitan untuk memahami materi yang diberikan oleh gurunya, karena guru tidak bisa menyampaikan materi secara langsung dengan tatap muka melainkan guru menyampaikan materi dengan aplilaksi whattsap dan menggunkan aplikasi lainnya. Hal

\footnotetext{
${ }^{7}$ Khoiruddin, dkk. 2009. Buku Pintar Bahasa Indonesia. Yogyakarta: Lentera Ilmu.
} 
tersebut akan sulit bagi siswa untuk memahami materi yang disapaikan oleh guru secara daring.

c. Rendahnya minat belajar

Siswa akan mulai jenuh dalam melakanakan pembelajaran yang dilakukan di rumah secara daring, dikarenakan pembelajaran daring itu membosankan dan siswa tidak lagi memiliki semangat dalam pembelajaran secara online. Siswa tidak mengumpulkan tugas yang diberikan oleh guru dan orang tua tidak mengingatkannya. Siswa males mengumpulkan tugas yang diberikan guru dikarenakan guru ketika memberikan tugas tidak tepat waktu misalnya memberikan tugas dpagi hari tidak bisa langsung disampaikan kepada siswa melainkan disampaikan pada siang hari sehingga siswa harus menunggu tugas dan manteri yang akan diberikan oleh guru lewat online, untuk itu siswa akan merasa bosan dan jenuh.

d. Signal yang tidak terjangkau

Geografis Desa Kumpulrejo terdiri dari dua daerah yang tidak rata, terdiri dari daratan rendah dan tinggi. Hal ini menjadikan jaringan signal tidak bisa menjangkau daerah secara rata. Ada yang menjangkau tapi kekuatan signalnya lemah. Jaringan yang kurang membaik itu juga akan menjadi pengambat dalam proses pembelajaran yang dilakukan dirumah secara daring.

Pembelajaran daring yang menggunakan jaringan internet dalam penugasan dan memberikan materi yang dikirim melalui whatsapp, membuka yutube, mengirim tugas mengunduh materi dan lain sebagainya itu akan membutuhkan jaringan signal yang kuat. Untuk itu anak SMP desa Kumpulrejo harus mencari lokasi yang signalnya kuat agar dapat mengakses pembelajaran yang diberikan oleh guru lewat jaringan internet.

e. Faktor ekonomi orang tua

Faktor ekonomi orang tua juga akan menjadi salah satu faktor tidak berjalannya proses pembelajaran yang dilakukan di rumah secara daring pada masa pandemi covid-19. Dari hasil wawancara peneliti terhadap orang tua anak SMP Desa Kumpulrejo mayoritas bekerja sebagai petani. Untuk kebutuhan sehari-hari saja beberapa orang tua masih kesulitan dalam mencukupi kebutuhannya, apalagi untuk membeli peralatan yang dibutuhkan anaknya dalam pembelajaran yang dilakukan secara daring seperti peralatan Hp/komputer, paket data internet dan lain sebagainya. Tidak semua orang akan berasal 
dari golongan menengah keatas. Tentun ini akan menjadi faktor penghambat siswa SPM di desa kumpulrejo dalam pembelajaran secara online.

f.Faktor Pendukung

Untuk memperlancar pelaksanaan pembelajaran daring selama pandemi covid-19 perlu pendukung oleh beberapa komponen diantanya yaitu: infrastruktur, sisitem dan aplikasi, konten, operator. ${ }^{8}$ Dengan adanya faktor pendukung sebagai berikut proses pembelajaran anak pada masa pandemi covid-19 akan berjalan dengan lancar.

2. Faktor pendukung merupakan hal yang menjadi dorongan agar suatu kegiatan tersebut dapat berjalan sesuai dengan yang diharapkan. Dalam prose pembelajaran yang dilakukan oleh anak SMP di Desa Kumpulrejo Kecamatan Parengan Kabupaten Tuban secara daring ada beberapa hal yang menjadi pendukung agar proses kegiatan pembelajaran dapat berjalan secara lancar diantaranya yang menjadi pendukung pada saat pembelajaran daring yaitu:

a. Dukungan orang tua

Dukungan atau support dari orang tua akan menjadi faktor pendukung dari proses kegiatan pembelajaran anak SMP dirumah pada masa pandemi covid-19 di Desa Kumpulrejo Kecamatan Parengan Kabupaten Tuban. Misalnya orang tua dalam mendukung dengan cara memancing dengan memberi hadiah bila mendapatkan nilai yang baik. Maka sorang anak akan lebih semangat lagi dalam belajar.

b. Fasilitas yang memadai

Dengan adanya fasilitas yang memadai proses kegiatan pembelajaran anak SMP yang dilakukan di rumah secara daring akan berjalan dengan baik sesuai keinginan. Fasilitas yang memadahi seperti HP yang sudah berandroit, data internet tercukupi dan signal yang lanjar.

c. Buku pelajaran (Buku Paket)

Buku pelajaran atau buku paket termasuk alat bantu ketika siswa tidak bisa memahami materi secara langsung yang disampaikan guru dalam proses pembelajaran daring yang dilakukan anak SMP desa Kumpulrejo, untuk itu siswa bisa membuka kembali buku pelajaran atau buku paket yang berisi materi yang disampaikan guru secara daring.

\footnotetext{
${ }^{8}$ Khoiruddin, dkk. 2009. Buku Pintar Bahasa Indonesia. Yogyakarta: Lentera Ilmu. Hal 102
} 


\section{d. Ekonomi yang tercukupi}

Berdasarkan dari observasi dan wawancara dengan orang tua dan anak SMP di Desa Kumpulrejo Kecamatan Parengan Kabupaten Tuban yaitu dengan adanya keadaan ekonomi yang tercukupi orang tua bisa memfasilitasi kebutuhan yang perlukan anak dalam proses pembelajaran yang dilakukan di rumah secara daring.

\section{Kesimpulan}

Pada bab ini dideskripsikan kesimpulan dari hasil penelitian yang berjudul peran orang tua dalam mendukung kegiatan pembelajaran anak SMP di rumah pada masa pandmei civid-19 yang sesuai rumusan masalah melalui metode observasi, wawancara dan dokumentasi dapat disimpulkan sebagai berikut:

1. Adapun peran orang tua dalam mendukung kegiatan pembelajaran anak SMP di rumah pada masa pandemi covid-19 di Desa Kumpulrejo Kecamatan Parengan Kabupaten Tuban ada berbagai jenis peran yang dilakukan oleh orang tua diantarannya yaitu:
a. Memberikan motivasi atau penyemangat pada anak
b. Orang tua sebagai fasilitator pada anak
c. Mengawasi anak dalam belajar

2. Adapun faktor yang menjadi penghambat dan pendukung kegiatan pembelajaran anak SMP di rumah pada masa pandemi covid-19 di Desa Kumpulrejo Kecamatan Parengan Kabupaten yaitu faktor yang menjadi penghambat dalam proses kegiatan pembelajaran anak diantaranya: kurunganya pengetahuan orang tua, sulit memahami materi, rendahnya minat belajar, signal yang tidak terjangkau, faktor ekonomi orang tua. Faktor pendukungnya antara lain yaitu: dukungan orang tua, fasilitas yang memadahi, buku paket, ekonomi yang tercukupi.

\section{Daftar Referensi}

Anies. 2020. Covid-19 Seluk Beluk Corona Virus yang Wajib Dibaca. Jogjakarta: Arruzz Media. Bungin, Burhan. 2003. Analisis Data Penelitian Kualitatif. Jakarta: PT Raja Grafindo.

Faizin, Muhammad. 2016. Peran Anak Dalam Menerapkan Pendidikan Agama Islam Pada Anak Usia Dini Di Desa Karangtinoto Kecamatan Rengel Kabupaten Tuban Tahun 2015. Tuban: STITMA. 
Basleman Anisah, Mappa Syamsu. 2011. Teori Belajar Orang Dewasa. Bandung: PT. Remaja Rosdakarya.

Graha, Chairinniza. 2007. Keberhasilan anak di tengah orang tua. Jakarta: PT. Elek Media Komputindo.

Gunawan, Imam. 2017. Metode Penelitian Kualitatif Teori dan Praktik. Jakarta: Bumi Aksara.

Ikhsan, Fuad. 2008. Dasar-Dasar Kependidikan. Jakarta: Rineka.

KBBI. Arti Kegiatan. (Onlen), (https://kbbi.web.id/kegiatan)

Kemdikbud. 2016. Kamus Besar Bahasa Indonesia. Jakarta : Balai Pustaka.

Khoiruddin, dkk. 2009. Buku Pintar Bahasa Indonesia. Yogyakarta: Lentera Ilmu.

M. Nur Abdul Hafizh, Suwaid. 2009. Properti Parenting; Cara Nabi Saw Mendidik Anak. Yogyakarta: Pro Media.

Maimunah, siti, dan Alif, Muhammad. 2020. Peran Guru, Orang Tua Metode dan Media Pembelajaran KBM di Masa Pandemi Covid-19. Banten : PT. 3M Media Karya Serang.

Mamik. 2015. Metodologi Kualitatif. Sidoarjo: Zifatama Publisher

Mansur. 2005. Pendidika anak usia dini dalam islam. Yogyakarta: pustaka belajar.

Moleong, Lexy J. 2019. Metodologi Penelitian Kualitatif. Bandung: PT. Remaja Rosdakarya.

Mujahidin, Firdaus. 2017. Strategi Mengelola Pembelajaran Bermutu. Bandung: PT. Remaja Rosdakarya.

Sa'adah, Umi. 2020. Peran Orang Tua Dalam Peningkatan Motivasi Belajar Matematika Pada Masa Pandemi Covid-19 (Studi Kasus) Siswa Smp Kelas Viii Di Desa Sungai Lebak Tahun 2020. Salatiga: IAIN Salatiga.

Sanjaya, Wina. 2006. Strategi Pembelajaran Berorientasi Standar Proses Pendidikan. Jakarrta: Kencana .

Sudarsana, Ketut dkk. 2020. Covid-19:Perspektif Pendidikan. Jakarta: Yayasan Kita Menulis.

Sugiono. 2016. Metoode Penelitian Pendidikan (Pendekatan Kuantitatif, Kualitatif, dan R\&D). Bandung: Alfabeta.

Sugiyono. 2015. Metode Penelitian Kuantitatif, Kualitatif dan R\&D,. Bandung: CV. Alfabeta, Desember, Cet ke-2.

Syahruddin, S. 2020. Pembelajaran Masa Pandemi Dari Konfesional Ke Daring . Pemeblajaran Pada Masa Pandemi : Dari Konvesional Ke Daring 
Widiswaro, Erwin. 2017. Inovasi Pembelajaran Berbasis Life Skill \& Enterpreneurship. Yogyakarta:Ar-Ruzz media.

Winarno. 2020. Covid-19 Pelajaran Yang Berharga Dari Sebuah Pandemic. Jakarta : PT. Gramedia Pustaka Utama. 